\title{
SYNTHESIS AND ANTIVIRAL ACTIVITY OF NEW 4- (PHENYLAMINO)THIENO[2,3-b]PYRIDINE DERIVATIVES
}

\author{
Alice M. R. Bernardino ${ }^{\mathbf{a}}$; Luiz C. S. Pinheiro ${ }^{\mathbf{a}}$, Vitor Francisco Ferreira; Alexandre R. Azevedo; \\ Jose W. de M. Carneiro ${ }^{b}$; Thiago M. L. Souza ${ }^{c}$ and Izabel C. P. P. Frugulhetti ${ }^{c}$ \\ "Universidade Federal Fluminense; Instituto de Quimica, Departamento de Quimica Orgầnica, Programa de \\ Pós-Graduação em Química Orgânica, Campus do Valonguinho, CEP 24210-150, Niterói - RJ, Brasil \\ bUniversidade Federal Fluminense, Instituto de Quimica, Departamento de Quimica Inorgânica

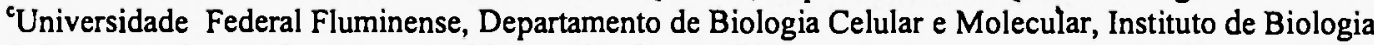 \\ *Corresponding author: E-mail address: alice@rmn.uff.br
}

\begin{abstract}
Several new 4-(phenylamino)thieno[2,3-b]pyridines (6a-e) were synthesized and tested against herpes simplex virus type 1 (HSV-1). For the first time one compound (62) of this heterocyclic system showed $86 \%$ of inhibitory indicating that these compounds retain antiviral potency in comparison to the parent pirazolo-pyridine derivatives. ${ }^{3}$
\end{abstract}

\section{Introduction}

The compounds thieno[2,3-b]pyridine (6) are structurally promising since it contains at least two motifs that could be easily modified: the thienopyridine and phenyl portions. Recently, a novel classes of thienopyrimidines and thienopyridines have been identified as potent inhibitors of VEGFR-2 kinase, which is the key component of the signaling pathway responsible for the sprouting and maturation of new blood vessels from tumors. ${ }^{1}$ Also, a new series of thienopyrimidines were synthesized and studied as inhibitors of dihydrofolate reductase from Pneumocystis carinii, Toxoplasma gondii, Mycobacterium avium. ${ }^{2}$

The synthesis of thieno[2,3-b]pyridine was first reported in 1913 and represents only one of six possible isomers. ${ }^{3}$ Their chemistry has been the subject of two reviews. ${ }^{4}$

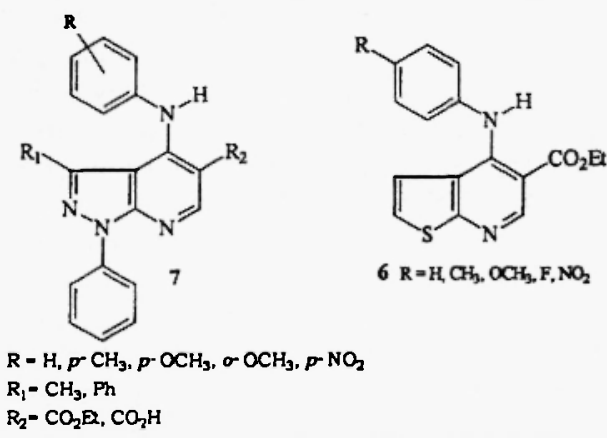

Since it was found that 4-anilino-l $H$-pyrazolo $[3,4-b]$ pyridine $(7)$ derivatives are effective nonnucleoside inhibitor of reverse transcriptase enzyme (NNRI) of HIV-l, several studies have been made by us and other groups in order to investigate the structure-activity relationships of these compounds and to improve their antiviral activity. ${ }^{5-7}$

\section{Results and Discussion}

In pursuit of our goal of finding new antiviral lead compounds, we report the synthesis of ethyl 4(phenylamino)thieno[2,3-b]pyridine-5-carboxylate (6a-e) analogues and evaluate their anti-HSV-1 activity.

The synthetic route used for preparing 4-(phenylamino)thieno[2,3-b]pyridines (6a-e) from 5carboethoxy-4-chlorothieno[2,3-b]pyridine (5) is straightforward, and it was accomplished according to the reaction sequence outlined in Scheme 1. $^{\text {B.11 }}$

The bis-(2-thienylammonium)hexachlorostannate (1) was condensed with diethyl ethoxymethylenemalonate (2) to give ethyl $\alpha$-carboethoxy- $\beta$-(N-2-thienylammonium) acrylate (3). The cyclization of (3) was carried out by refluxing it in downtherm and isolating the ethyl 4hydroxythienopyridine-3-carboxylate (4) by precipitating from petroleum ether. By NMR analysis it was possible to observe that the hidroxy tautomer (4) predominates over the quinolone, which was easily chlorinated in refluxing phosphorus oxychloride producing 5-carboethoxy-4-chlorothieno[2,3-b]pyridine (5). For producing the target compounds an equimolar mixture of anilines and (5) were refluxed for two hours producing the new products, ethyl 4-(phenylamino)thieno[2,3-b]pyridine-5-carboxylate (6a-e), were isolated 
in good yields. The structures of the compounds were elucidated by ${ }^{1} \mathrm{H}$ and ${ }^{13} \mathrm{C}$ NMR experiments $\left({ }^{1} \mathrm{H}, \mathrm{DEPT}\right.$, ${ }^{1} \mathrm{H}-{ }^{-} \mathrm{H}-\mathrm{COSY}, \mathrm{HETCOR}$ ) and, by elemental analysis.

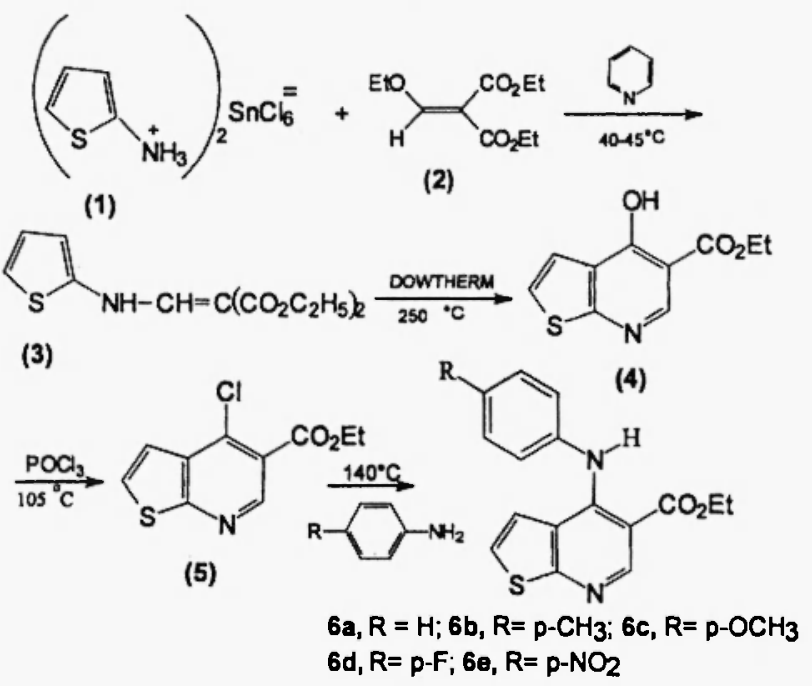

The herpes simplex virus type-1 (HSV-1) is a neurotropic, DNA-double-strand-linear virus, that undertakes latency in trigemea ganglia. The virions consists of a lipidic envelop, and both proteic tegument and nucleocapsid. The HSV-1 entry into cells is a complex process involving the interactions between HSV attachment proteins and cell surface heparan sulfate proteoglycan receptors, followed by fusion of viral envelope glycoproteins with the host cell plasma membrane. ${ }^{12}$ African green monkey kidney cells (VERO) were used for all experiments. They were cultured in Dulbecco's modified eagle medium (DMEM; GIBCO/BRL) supplement with $8 \%$ calf serum and $2 \%$ fetal calf serum (FCS), $100 \mathrm{U} / \mathrm{mL}$ penicillin, 100 $\mu \mathrm{g} / \mathrm{mL}$ streptomycin and $250 \mu \mathrm{g} / \mathrm{mL}$ anphotericin $\beta$. As the cells became confluent, they were subcultured following this procedure: - wash with PBSlx-EDTA, trypsin 0,25\% and resuspended in culture medium. All the cells were incubated at $37^{\circ} \mathrm{C}$ in a $5 \% \mathrm{CO}_{2}$. We used an acyclovir resistant strain (HSV-1[ACV]). Monolayers in $25 \mathrm{~cm}^{2}$ bottles were infected by HSV-1 at 0.1 multiplicity of infection (m.o.i.) and harvested at $24 \mathrm{~h}$ post infection (p.i.) by freezing and thawing and centrifuged at $3000 \mathrm{rpm}$ in microfuge at $4{ }^{\circ} \mathrm{C}$ for 20 minutes. The supernatant was collected and stored at $-70^{\circ} \mathrm{C}$ for use. ${ }^{13}$

The antiviral activities of the derivatives were investigated according to the computation of $50 \%$ end point method described by Reed and Mounch. ${ }^{14}$ Vero cells grown in 96-well plate were infected with 1 m.o.i. of HSV type 1 for $\mathrm{lh}$ at $37^{\circ} \mathrm{C}$. After this period, virus inocullum was replaced by complete culture medium, containing or not $50 \mu \mathrm{g} / \mathrm{mL}$ of the derivatives. At 72 hours post infection (p.i.) culture medium was harvested and virus titer of each sample was determined in terms of the $50 \%$ tissue culture dose (TCID 50/mL)by end point dilution.

The antiviral effects of five new thienopyridine derivatives (6a-e) were show in Table 1 . The compound $6 \mathrm{a}$ was able to inhibit HSV-1 infection near to $86 \%$. It is important to emphasize that compounds (6a-e) were not cytotoxic to host cells at the some concentration, suggesting that they may affect selectively a specific step in the virus replication cycle.

Table 1: Antiviral activity of the thienopyridine (6a-e) at $50 \mu \mathrm{M}$ on HSV-1

\begin{tabular}{l|l}
\hline $\begin{array}{l}\text { Compounds } \\
(50 \mu \mathrm{M})\end{array}$ & $\begin{array}{l}\text { Herpes simplex virus type 1 } \\
(\% \text { of Inhibition) }\end{array}$ \\
\hline $\mathrm{ACV}(10 \mu \mathrm{M})$ & $82 \pm 8$ \\
\hline $6 \mathrm{a}$ & $86 \pm 2$ \\
\hline $6 \mathrm{~b}$ & $42 \pm 4$ \\
\hline $6 \mathrm{c}$ & $-7 \quad \pm 3$ \\
\hline $6 \mathrm{~d}$ & $\mathrm{ND}$ \\
\hline $6 \mathrm{e}$ & $58 \pm 5$ \\
\hline
\end{tabular}


ND - Not determined; Vero cells $\left(2 \times 10^{5}\right.$ cells / well) were infected with HSV-1 at 1 pfu / cell for 1 hour at $37^{\circ} \mathrm{C}$. At zero time post infection, virus inocullum was replaced by culture medium containing or not derivatives. After 72 hours p.i., virus titer of each simple was determined by $50 \%$ tissue culture infective dose (TCID $50 / \mathrm{mL}$ ). The data are mean values from one of the representative experiments. The date shown in this table were analyzed by EXCEL software for $P$ value, by students $t$-test. In this table the $\mathrm{P}<0,01$ for all data.

Accordling the results showed in Table 1, three thieno[2,3-b]pyridines (6a,b and 6e) showed activity and $6 \mathrm{a}$ showed an inhibitory activity above $86 \%$ at $50 \mu \mathrm{M}$. The fact that these compounds exerted minimal effects on cellular DNA synthesis trend for low cellular toxicity may indicate that should be tested against other type of viruses as HIV-1.

In order to understand the conformational behavior of these systems, we undertook a conformational analysis for each derivative, looking for the potential energy surface for rotation about relevant single bonds.

The geometry of all derivatives was fully optimized using the semi-empirical AMI method in the MOPAC 93 package. Minimal energy conformations were determined by $360^{\circ}$ rotation (in $30^{\circ}$ step) around the $\mathrm{C}_{4}-\mathrm{N}$ single bond. These led to four minima, with $\mathrm{C}_{32}-\mathrm{C}_{4}-\mathrm{N}-\mathrm{C}_{1}$. dihedral angles of $30^{\circ},-30^{\circ}, 150^{\circ}$ and $150^{\circ}$. In all cases the $\pm 30^{\circ}$ conformers are the most stable ones. In these conformations the lone-pair on the nitrogen atom preferentially delocalizes into the thienopyridine ring. Steric repulsion does hinder the eclipsing between the phenyl and the thienopyridine rings, which otherwise would lead to a dihedral angle of $0^{\circ}$. Substituents in the phenyl ring modulate the delocalizaton of the nitrogen lone-pair. Electrons donating substituents help to delocalize the lone-pair into the thienopyridine ring, therefore making all the system more planar. In contrast, electron withdrawing substituents, like the $\mathrm{NO}_{2}$ group for example, attract the nitrogen lone-pair to the phenyl ring, therefore making the $\mathrm{C}_{34}-\mathrm{C}_{4}-\mathrm{N}-\mathrm{C}_{1}$. dihedral angle in the minimum energy conformation higher (about $60^{\circ}$ ). In any way, the potential energy surface in the region between $-60^{\circ}$ and $+60^{\circ}$ is rather flat. The energy barrier in the $0^{\circ}$ conformation is lower than $0,5 \mathrm{kcal} / \mathrm{mol}$ for the case of electron donating substituents, increasing to about $2 \mathrm{kcal} / \mathrm{mol}$ for electron withdrawing substituents. In contrast the energy for conversion to the $\pm 150^{\circ}$ conformer is considerably higher, at least $8-10 \mathrm{kcal} / \mathrm{mol}$. Therefore these compounds do exist in conformations with the $\mathrm{C}_{32}-\mathrm{C}_{4}-\mathrm{N}-\mathrm{C}_{1}$. dihedral angle in the range $-60^{\circ}$ to $+60^{\circ}$. For rotation around the $\mathrm{C}_{4}-\mathrm{C}_{5}-\mathrm{C}_{8}-\mathrm{O}_{1}$ " dihedral angle the conformational behavior is more simple. Minima were found for dihedral angles of $0^{\circ}$ and $180^{\circ}$. These conformations are stabilized by $\mathrm{N}-\mathrm{H}-\mathrm{-O}=\mathrm{C}$ hydrogen bond. The most stable conformer (by about $2 \mathrm{kcal} / \mathrm{mol}$ ) is that where the amine hydrogen interacts with the carbonyl oxygen (dihedral angle of $180^{\circ}$ ). The existence of hydrogen bonds to the carbonyl oxygen is confirmed by the IV absorption band at approximately $1670 \mathrm{~cm}^{-1}$, some $40-50 \mathrm{~cm}^{-1}$ lower than the usual ester $\mathrm{C}=\mathrm{O}$ stretching. The barrier for interconvertion between the two minima is in the order of $3 \mathrm{kcal} / \mathrm{mol}$.
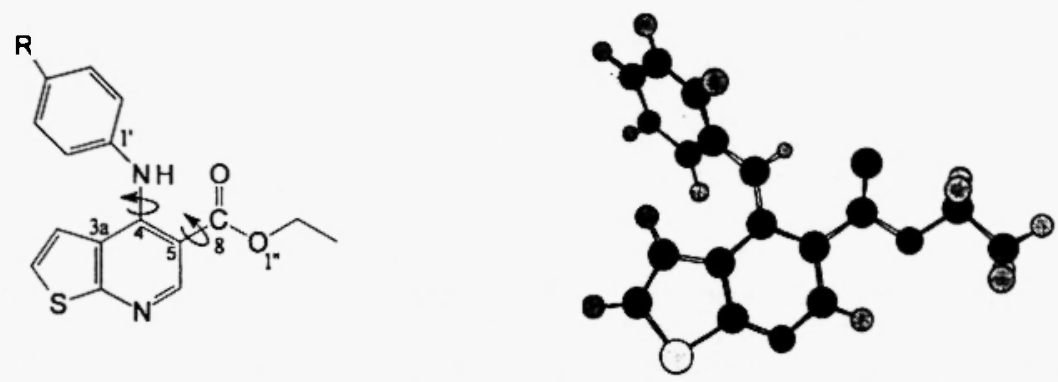

\section{Conclusions}

Five new ethyl 4-(phenylamino)thieno [2,3-b]pyridine-5-carboxylate derivatives (6a-e) were synthesized in good yields by a brief procedures, which is scalable and easy to produce new analogues. The compound 6 a exhibited in vitro inhibitory activity above $86 \%$ at $50 \mu \mathrm{M}$ against HSV-1. Minima energy conformations were calculated using the semi-empirical AMI method in the MOPAC 93 package. For rotation around the $\mathrm{C}_{4}-\mathrm{N}$ bond the minima with $\mathrm{C}_{3}-\mathrm{C}_{4}-\mathrm{N}-\mathrm{C}_{1}$. dihedral angle of $\pm 30^{\circ}$ are the most stable one, in all cases, (except the $6 \mathrm{e}$ ). For the case of the $\mathrm{C}_{5}-\mathrm{C}_{8}$ bond the minimum with $\mathrm{C}_{4}-\mathrm{C}_{5}-\mathrm{C}_{8}-\mathrm{O}_{1}$. dihedral angle of $180^{\circ}$ is the most stable. The present results of the activity of thienopyridine derivatives against HSV-1 are very promising. It will be suitable to synthesize new derivatives of the thienopyridine analogues searching for a better activity and the studies of the mechanism of action. 


\section{Experimental}

The 'H Nuclear Magnetic Ressonance (NMR) spectra were obtained from Varian model Unity Plus spectrometer operating at $300.00 \mathrm{MHz}$ spectrometer using tetramethylsilane as internal standard. The chemical shifts $(\delta)$ are reported in ppm and the coupling constants (J) in Hertz. Fourier transform infrared (FT IR) absorption spectra were recorded in a Perkin-Elmer mode Spectrum One FT-IR spectrophotometer. The solid samples were measured using potassium bromide pellets. Elemental analysis were determined on a Perkin-Elmer 240 and are in full agreement with the calculated values. Melting points (m.p.) were determined with a Fisher-Johns apparatus. TLC was carried out using silica gel F-254 Glass Plate $(20 \times 20 \mathrm{~cm})$. All other reagents and solvents used were analytical grade.

General procedure: Ethyl 4-(phenylamino)thieno[2,3-b]pyridine-5-carboxylate (6a-e)

An equimolar ( $5 \mathrm{mmol}$ ) amounts of (5) and the appropriate aniline were heated in a silicone oil bath at $140^{\circ} \mathrm{C}$ for 2 hours. The mixture was concentrated in vacuum producing a residue, which was diluted with $\mathrm{CH}_{2} \mathrm{Cl}_{2}$ and purified by preparative silica gel plates $\left(\mathrm{CH}_{2} \mathrm{Cl}_{2}\right)$.

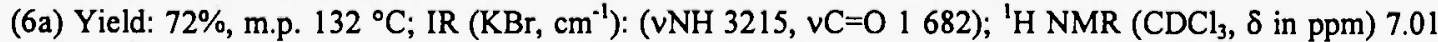
$(\mathrm{d}, J=6.0 \mathrm{~Hz}) ; 6.33$ (d, $J=6.0 \mathrm{~Hz}) ; 9.00(\mathrm{~s}) ; 7.41-7.19(\mathrm{~m}) ; 10.45(\mathrm{~s}) ; 4.42$ (q, $J=7.2 \mathrm{~Hz}) ; 1.44(\mathrm{t}, J=7.2$ $\mathrm{Hz}$ ).

(6b) Yield: $44 \%$; m.p. $90^{\circ} \mathrm{C}$; IR $\left(\mathrm{KBr}, \mathrm{cm}^{-1}\right):(v \mathrm{NH} 3252, v \mathrm{C}=\mathrm{O} 1666) ;{ }^{1} \mathrm{H}$ NMR $\left(\mathrm{CDCl}_{3}, \delta\right.$ in ppm) 6.98 $(\mathrm{d}, J-6.0 \mathrm{~Hz}) ; 6.30(\mathrm{~d}, J=6.0 \mathrm{~Hz}) ; 8.8(\mathrm{~s}) ; 7.19-7.08(\mathrm{~m}) ; 10.38(\mathrm{~s}) ; 2.39(\mathrm{~s}) ; 4.40(\mathrm{q}, J=7.2 \mathrm{~Hz}) ; 1.43(\mathrm{t}, J$ $=7.2 \mathrm{~Hz}$ ).

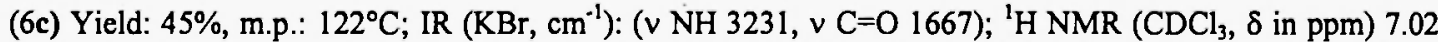
$(\mathrm{d}, J=6.0 \mathrm{~Hz}) ; 6.20$ (d, $J=6.0 \mathrm{~Hz}) ; 8.99$ (s); 7.20-6.93 (m); 10.59 (s); 3.87 (s); 4.43 (q, $J=7.2 \mathrm{~Hz}) ; 1.45$ (t, $J$ $=7.2 \mathrm{~Hz}$ ).

(6d) Yield: 72\%; m.p. $105^{\circ} \mathrm{C}$; IV $\left(\mathrm{KBr}, \mathrm{cm}^{-1}\right)$ : ( $\left.\mathrm{v} \mathrm{NH} \mathrm{3255,} \vee \mathrm{C}=0 \mathrm{O} 1668\right) ;{ }^{1} \mathrm{H} \mathrm{NMR}\left(\mathrm{CDCl}_{3}, \delta\right.$ in ppm) 7.07 $(\mathrm{d}, J=6.0 \mathrm{~Hz}) ; 6.26(\mathrm{~d}, J=6.0 \mathrm{~Hz}) ; 9.01 ;(\mathrm{s}) ; 7.22$ (dd, $J=9.0$ and 4.5$) ; 7.16(\mathrm{dd}, 9.0 ; 8.1) ; 10.53$ (s); 4.44 (q, $7.2) ; 1.45(\mathrm{t}, 7.2)$.

(6e) Yield: $36 \%$; m.p. $150^{\circ} \mathrm{C}$; IR $\left(\mathrm{KBr}, \mathrm{cm}^{-1}\right)$ : $(\nu$ NH 3217, $\vee \mathrm{C}=\mathrm{O} 1687)$; ${ }^{1} \mathrm{H}-\mathrm{NMR}\left(\mathrm{CDCl}_{3}, \delta\right.$ in ppm) 7.22 (d, 6.0); 6.46 (d, 6.0); 9.09 (s) 7.48 (dd, $J=9.0$ and $2.1 \mathrm{~Hz}$ ); 8.12 (dd, $J=9.0$ and $2.1 \mathrm{~Hz}$ ); 10.66 (s); 4.46 (q, $J=7.2 \mathrm{~Hz}$ ); $1.46(\mathrm{t}, J=7.2 \mathrm{~Hz})$.

Acknowledgments

We thank the Conselho Nacional de Desenvolvimento Científico e Tecnologico (CNPq), Coordenação de Aperfeiçoamento de Pessoal Docente (CAPES) and the Fundaçăo de Amparo à Pesquisa do Estado do Rio de Janeiro (FAPERJ) for the financial support.

\section{References}

1. Munchhof, M. J.; Beebe, J.S.; Casavant, J.M.; Cooper, B.A.; Doty, J.L.; Higdon, R.C.; Hillerman, S.M.; Soderstrom, C.I.; Knauth, E.A.; Marx, M.A.; Rossi, A.M.K.; Sobolov, S.B.; Sun, J. Bioorg. Med. Chem. Lett. 14, 21, (2004).

2. Donkor, I.O.; Li, H.; Queener, S.F. Eur. J. Med. Chem. 38, 605-611, (2003).

3. Webber, J.S.; Woolley, R.G. J. Mol. Struct. 341, 171, (1995).

4. John, M.B.; The Thienopyridines, Katritzky A.R. and Boulton A., (Eds.), Academic Press, New York, pp. $65-118,1977$.

5. Bernardino, A. M. R.; Ferreira, V. F.; Fontoura, G. A. T. I.; Frugulhetti, C. P. P.; Lee, M. Y.; Romeiro, G. A.; Souza, M. C. B. V.; Sá, P. M. J. Braz Chem. Soc. 7, 273, (1996).

6. Azevedo, A.R.; Ferreira, V.F.; Mello, H.M.; Ferreira, L.R.L.; Jabor, A.V.; Frugulhetti, I.C.P.P.; Pereira, H.S.; Moussatche, N.; Bernardino, A.M.R. Heterocycl. Comm. 8, 427, (2002).

7. Azevedo, A.R.; Frugulhetti, I.C.C.P.; Khan, M.A.; Khakwani, S.; Bernardino, A.M.R. Heterocycl. Comm. 8, 47, (2002).

8. Khan, M.A.; Rolim, A.M.C. Heterocycles 12, 701, (1979).

9. Khan, M.A.; Rolim, A.M.C.; Guarçoni, A.E. J. Heterocycl. Chem. 20, 475, (1983).

10. Khan, M.A.; Rolim, A.M.C. Monatshefte fur Chem. 114, 1079, (1983).

11. Khan, M.A.; Guarçoni, A.E. J. Heterocycl. Chem. 14, 807, (1977).

12. Geraghty, R.J.; Jogger, C.R.; Spear, P.G., Virology 268, 147-158, (2000).

13. Kuo, Y.C.; Chen, C.C.; Tsai, W.J.; Ho, Y.H. Antiviral Res. 51, 95, (2001).

14. Reed, B.; Mounch, M. Am. J. Virol. 27, 492, (1938).

\section{Received on July 25, 2004.}

